\title{
NON-FORMAL AND INFORMAL LEARNING CONDITIONS AS EXPERIENCED AND PERCEIVED BY TECHNICAL STAFF AND HR PROFESSIONALS*
}

\author{
Raimonda Alonderiené, ** Goda Sabaliauskaitè ${ }^{* * *}$
}

Received: 17. 5. 2017

Original scientific paper

Accepted: 3. 12. 2017

UDC 005.96:629.7.02(474.5)

\begin{abstract}
The purpose of the paper is to investigate what are the non-formal and informal learning conditions as these are experienced on a daily basis by technical staff and perceived by HR managers in the aviation sector in Lithuania. Qualitative empirical research using in-depth, semistructured interviews with two HR managers and eight technical employees of the two largest Lithuanian aviation companies was conducted. The research results have revealed that, despite
\end{abstract}

\section{INTRODUCTION}

The competence development is identified as one of the major recent challenges (Vaiginiené, Alonderienè, Pilkienè, Ramonienè, Savanevičienè and Stankevičiūtè, in press) and aviation sector is no exception (Kim and Park, 2014). According to the data provided by the Air Transport Action Group (ATAG), currently there are more than 62 million people working in the aviation and related industries all over the world. In Lithuania, Avia Solutions Group, the company providing various aviation business solutions through its 17 subsidiaries employs more than the fact that the learning conditions were rather favorable in the analyzed companies, there were certain gaps between the perceptions of the $H R$ managers and the experiences of technical staff, especially as concerns the areas of high degree of exposure to changes and managerial responsibilities.

Keywords: non-formal and informal learning, aviation sector, HR managers, technical staff, Lithuania

1200 people. Many of them work in a highly technical environment which is subject to numerous European and global regulations and requirements. Due to the on-going changes in those requirements as well as the technologies involved in the manufacturing process within the sector, research into the training and learning processes among aviation staff is of particular importance on both practical as well as theoretical levels.

Companies invest in the development of formal competence but more informal ways of learning are becoming increasingly common (Becker and Bish, 2017). Research on

* Note. The paper has been previously presented and discussed at EURAM'15 conference. We appreciate the comments of the reviewers and conference participants who helped us to shape the final version of the paper.

** Raimonda Alonderiené, PhD, associate professor. ISM University of Management and Economics, Ausros Vartu str.7A, Vilnius, Lithuania. Phone: +37061115611 E-mail: raimonda.alonderiene@ism.lt

*** Goda Sabaliauskaite, Kauko al. 11-5, Kaunas, Lithuania. Phone: +370 672 96933. E-mail: godishius@yahoo.co.uk 
non-formal and informal learning in the aviation sector is still scarce (few examples include Wofford, Ellinger and Watkins, 2013; Mavin and Roth, 2015).

Human Resource department is typically responsible for training/learning management in companies. However, many large, globally operating enterprises tend to maintain HR departments in proximity (both geographically and on an organizational level) to the operational departments in which the majority of company employees produce company products or generate services. As a result, the perceptions of HR managers with regard to workplace learning and training may significantly differ from the actual learning of aviation technical staff. Therefore, the aim of the paper is to investigate what are the non-formal and informal learning conditions as these are experienced by technical staff and perceived by HR managers in the aviation sector in Lithuania.

The paper consists of the following parts. Literature review reveals the concepts of non-formal and informal learning in general as well as their conditions. It also presents the role of HR professionals in learning management. The methodology part describes the theoretical background and framework of the research based on Skule (2004). The research findings part reveals the prevalent non-formal and informal learning conditions in two aviation companies in Lithuania. The paper is concluded by discussion and conclusion parts.

\section{LITERATURE REVIEW}

\subsection{The analysis of non-formal and informal learning}

The analysis of non-formal and informal learning starts with the term of lifelong learning. According to Eurostat (2000), "lifelong learning encompasses all purposeful learning activity, whether formal, non-formal or informal, undertaken on an ongoing basis with the aim of improving knowledge, skills and competence". Formal learning takes place in educational training institutions and provides officially recognized qualifications and diplomas. According to A Memorandum on Life-long Learning (2000), non-formal learning takes place alongside the mainstream systems of education and training. It may be provided in the workplace and through the activities of civil society organizations and groups (such as in youth organizations, trades unions and political parties). Informal learning is a natural accompaniment to everyday life. Unlike formal and non-formal learning, informal learning is not necessarily intentional learning, and so may well not be recognized even by individuals themselves as contributing to their knowledge and skills (Alonderiene, 2010).

Although Eurostat (2000) and A Memorandum on Life-long Learning (2000) provided the definitions a while ago and focused on the society in general, similar notions are still used in the current research on non-formal (e.g. Mok, 2011) and informal learning (e.g. Becker and Bish, 2017) at workplace. It is highly important to point out that whilst the distinction between the methods of nonformal and informal learning provided in the definitions is rather clear, in real life situations and working environments this distinction is far from explicit. In fact, one has to consider a variety of formal elements of learning in the situations of informal learning context and vice versa (Malcolm, Hodkinson, and Colley, 2003). Therefore, in this paper we follow the notion of Malcolm et al. (2003) and Henriksen \& Børgesen (2016) who investigate non-formal and informal learning as non-strictly distinct. Instead, the concepts will be treated as overlapping and commonly observed as 'togetherness'. 


\subsection{The analysis of the HR function in non-formal and informal learning}

In the first decade of the new millennium the HR management strategy across the world was largely shaped by the global economic development. As a result, the HR function has gradually shifted away from its traditional function-oriented role towards being the strategic component of value creation (Kazlauskaite and Buciuniene, 2010). The issue of HR function is of great relevance because the question of training responsibility in terms of task allocation between HR and line managers is one of the primary problems to be addressed.

According to the findings of Kazlauskaite and Buciuniene (2010), line managers in Lithuania were mostly responsible for the management of remuneration $(49.5 \%)$ as well as hiring and firing (35.3\%), whilst HR managers were in charge of the selection, training and career advancement processes. However, in their function the latter were closely cooperating with the former (Kazlauskaite and Buciuniene, 2010). The expected role of an HR manager in the workplace learning is clearly defined by Zuzevičiūte and Teresevičiené (2010): to support and organize learning, to inform employees about opportunities for learning, especially the ones in lower positions, etc. However, it was evidenced that while HR managers might be competent in formal training, many of them lack necessary knowledge on informal learning amongst employees (Chivers, 2011). Therefore, involving HR managers in the research seems rather relevant.

\subsection{The existing research on non- formal and informal learning conditions}

Previous research on non-formal and informal learning addresses various issues: how learning happens (Ha, 2008; Borgesen,
Nielsen and Henriksen, 2016), recognition of learning (Garnett and Cavaye, 2015), the relationship between non-formal and informal learning (Malcolm et al., 2003), non-formal and informal learning in different industries, such as aviation (Wofford at el., 2013; Mavin and Roth, 2015), health (Clarke, 2005; Bjørk, Tøien and Sørensen, 2013; Kyndt, Vermeire and Cabus, 2016), IT (Ha, 2008), or employees of different levels in organizations: "regular" (Kyndt, Dochy and Nijs, 2009), low-qualified employees (Kyndt, Govaerts, Keunen and Dochy, 2013), professionals (Cheetham and Chivers, 2001) and managers (Alonderiene, 2010; Borgesen et al., 2016; Becker and Bish, 2017).

Furthermore, it is worth considering a few aspects of non-formal and informal learning. Firstly, informal learning in many cases is unintentional, accidental and might not be recognized by the learners themselves (Alonderiene, 2010). Secondly, as mentioned before, in multiple instances it may be rather hard to separate the two (Malcolm et al., 2003). Therefore, it is wise to consider the conditions which facilitate non-formal and informal learning.

Clarke (2005) has identified the workplace conditions which influence workplace learning versus training outcomes. He found that empowerment, effective communication and opportunities for reflection as well as job challenge are related to learning outcomes as opposed to training outcomes.

Another survey on informal training among flight instructors (Wofford et al., 2008) revealed that referring to past learning experiences (experience of being a student herself/himself), collaboration with colleagues and trial and error were the most common factors when determining the success of informal learning among the respondents. This may suggest that in order to facilitate the most effective conditions for 
fostering a learning culture in the workplace, managers should consider placing themselves in the role of a learner (trainee) whilst having past experience in that role is in itself exceptionally valuable when drawing upon any training practices in the workplace.

The research findings of Wofford et al. (2008) are complemented by $\mathrm{Ha}$ (2008) who has noticed the importance of collaboration with colleagues in workplace learning (working together with more experienced colleagues, talking to other colleagues) as well as Lohman (2006), Kyndt et al (2016) and Schurmann and Beausaert (2016). The latter survey has also identified the impact of support and feedback from supervisors on informal learning (Schurmann and Beausaert, 2016). Lohman (2006) adds that the lack of time and funds hinder informal learning.

Kyndt et al. (2009) have confirmed that employees of different functions and age in different types of organizations have access to different conditions of non-formal and informal learning. For instance, young employees with little previous experience have more access to "being coached", workers have most access to "being coached" and "coaching others" type of learning conditions (p. 380-381).

In the research on informal learning amongst nurses (Bjørk et al., 2013) the researchers identified particular 'learning arenas' where the opportunities for informal learning were exceptionally plentiful: the staff room, the meeting room and the patient rooms. The infrastructure was found to have significant influence on informal learning in other surveys as well (Hunter and Cox, 2014).

The wide range of surveys on non-formal and informal learning conditions presented shows that they cover different sectors, geo- graphical locations and age groups. The nonformal and informal learning conditions can be summed up as follows: individual conditions (reflection or taking a role), group conditions (talking to others, collaboration, being coached), and physical environment where learning happens (staff room, meeting room).

The next chapter focuses on learning conditions in the aviation sector by using the model of Skule (2004).

\subsection{Non-formal and informal learning conditions in the aviation sector}

Table 1 provides a list of conditions which facilitate learning in the workplace, as identified by Skule (2004). As discussed above, ability to measure the level of opportunities with regard to informal learning in the workplace can be rather difficult. That is why exploring the presence of relevant conditions for learning can help.

One would rightfully suspect that such working environments as an airport ramp or an aircraft maintenance hangar abound in ongoing innovations and changes. According to Ellstrom (2010), experts have lately been increasingly inclined to draw a direct link between the presence of innovations and learning; innovations have become a function of facilitating various learning activities and the acquisition of knowledge (Ellstrom, 2010).

As concerns a high exposure to demands, aviation maintenance and ground handling have been long considered to be 'high reliability' working environments next to such fields as anesthesiology as well as the industry of nuclear power and offshore oil platforms (Flin et al., 2002; Hagemann et.al., 2012). This statement is further reinforced by the findings of Gijbels, Raemdonck, 
Vervecken and Herck (2012) where job-related demands and associated control were significantly positively linked to the learning behavior in the workplace. may threaten the industry players already faced with harsh competition due to the lack of professionals. On the other hand, an exchange of information is vital in prevent-

Table 1: A list of conditions which facilitate non-formal and informal learning

\begin{tabular}{|l|l|l|}
\hline & Condition & Explanation of the variables included in each learning condition \\
\hline 1 & $\begin{array}{l}\text { A high degree of } \\
\text { exposure to changes }\end{array}$ & $\begin{array}{l}\text { Learning intensive jobs are characterized by more frequent changes in } \\
\text { technology (products and processes) and working methods. }\end{array}$ \\
\hline 2 & $\begin{array}{l}\text { A high degree of } \\
\text { exposure to demands }\end{array}$ & $\begin{array}{l}\text { Learning intensive jobs are characterized by more exposure to } \\
\text { demands from customers, managers, colleagues or the group chain } \\
\text { that the company belongs to. }\end{array}$ \\
\hline 3 & $\begin{array}{l}\text { Managerial } \\
\text { responsibilities }\end{array}$ & $\begin{array}{l}\text { Learning intensive jobs are characterized by accompanying } \\
\text { managerial responsibilities in the job. These are not high-level } \\
\text { managerial responsibilities, as 40\% of the responsibilities respondents } \\
\text { claimed to have them. Rather it may typically be allocated } \\
\text { responsibilities for decision making concerning certain tasks, project } \\
\text { management, work group management and so forth. }\end{array}$ \\
\hline 4 & $\begin{array}{l}\text { Extensive } \\
\text { professional contacts }\end{array}$ & $\begin{array}{l}\text { Learning intensive jobs are characterized by better opportunities to } \\
\text { participate in professional forums outside the company, professional } \\
\text { or occupational networks, trade fairs, conferences. etc., and by more } \\
\text { extensive learning conducive contacts with customers or suppliers. }\end{array}$ \\
\hline 5 & $\begin{array}{l}\text { Superior feedback } \\
\text { learning intensive jobs are characterized by better opportunities to } \\
\text { learn from seeing direct results of the work. }\end{array}$ \\
\hline 6 & $\begin{array}{l}\text { Management support } \\
\text { for learning }\end{array}$ & $\begin{array}{l}\text { Learning intensive jobs are characterized by a stronger feeling by the } \\
\text { employee that management is supportive and encouraging of learning. }\end{array}$ \\
\hline 7 & $\begin{array}{l}\text { Rewarding of } \\
\text { proficiency }\end{array}$ & $\begin{array}{l}\text { Learning intensive jobs have organizational surroundings that reward } \\
\text { proficiency by means of higher wages, allocation of more interesting } \\
\text { tasks or improved career opportunities. }\end{array}$ \\
\hline
\end{tabular}

Source: Skule (2004)

Managerial responsibilities in the aviation sector are defined as "typically allocated responsibilities for decision making concerning certain tasks, project management, work group management and so forth" (Skule, 2004, p. 14). This definition implies that in the environments where a lot of tasks involve team effort (and both aviation maintenance and ground handling segments certainly do), employees are often exposed to certain managerial responsibilities.

In terms of exposure to extensive professional contacts, the sector of aviation is a very tricky environment. On the one hand, active participation in professional networks ing errors commonly leading to serious accidents or incidents. However, the pros of maintaining professional contacts unarguably outweigh the potential cons and lead to learning experiences as confirmed by Baert and Govaerts (2012) who state that "the social working environment relates to the ways and opportunities in which employees can have contact with each other and by this means learn from each other" (p. 540).

When considering the implications of effective feedback within organizations, we have to take into account both peer and supervisor feedback. According to Eraut (2011), working with colleagues allows "the 
learner to see how a colleague reads situations, monitors them and makes decisions. These activities are largely tacit and difficult to explain" (p. 9). In a highly technologyoriented work environments feedback from one's colleagues is of no less importance, or even more important than constructive feedback from one's superiors. The latter concept is described in a cross-sectional case study conducted in a high-tech industry which revealed a direct link between high quality upward feedback and the self-determination of employees who were more likely to positively relate to the company, and they demonstrated higher competence and autonomy (Bauer and Mulder, 2006).

Supervisor feedback is also related to management support and recognition. Madzar (1997) argues that the century when feedback was viewed as a mere means for managers to evaluate the performance of their employees is over. Instead, nowadays employees tend to actively seek feedback in order to avoid feeling uncertain, assess their own competence, raise self-esteem and form a positive image in the eyes of one's peers and management. Multiple studies have shown that negative feedback may result in poor attitudes, reluctance to learn from one's own mistakes and unwillingness to correct one's behavior (Meyer and Walker, 1961; Fedor, Eder and Buckley 1989; Brett and Atwater, 2001; Mulder and Ellinger, 2013; Zhang and Ng, 2012).

The last condition which facilitates workplace learning is related to the way that companies reward their employees for proficiency. Although one may think that there are only several types of rewards, an Australian scholar Cacciope (1999) has found as many as forty four specific tools that companies can use. All of them, however, fit into one of the following categories: (i) money/prizes/ gifts; (ii) recognition and praise awards; and (iii) development/ empowering work (Cacioppe, 1999). The last category suggests that the assignment of more responsibilities can, in fact, be viewed as a type of reward for proficiency.

Taking into account the findings of studies described above, only few of them (e.g. Wofford et al., 2008) cover the aviation sector. However, we did not find any research on non-formal and informal learning conditions in aviation sector in Lithuania. Therefore, this survey is intended to fill in the existing gap.

\section{METHODOLOGY OF THE EMPIRICAL RESEARCH}

\subsection{Research aim}

The main purpose of the empirical research is to investigate and analyze the difference between the perceptions of HR managers and the experience of hangar/ramp employees in the aviation sector in Lithuania with regard to non-formal and informal learning conditions in the workplace. As the research problem revolves around the 'perceptions' and the 'experiences', a qualitative analysis is the method best suited to achieve the goals and objectives of the empirical research into the subject. It extends the previous qualitative research of Wofford et al. (2013), Spaan et al. (2016), Schurmann and Beausaert (2016), Becker and Bish (2017) and others. The content analysis was used as data analysis method.

The aviation sector in Lithuania was selected because of the highly intense and industry-specific training requirements as well as the aforementioned role of human factors in the so called 'high reliability' industries (Flin, O'Connor and Mearns, 2002). Moreover, both of the companies satisfied the conditions of (a) being substantially large 
(around 220 employees in Company A and almost 700 employees in Company B) and (b) maintaining HR departments in proximity (both geographically and on an organizational level) of operational departments studied (aircraft maintenance hangar and airport ramp).

\subsection{Research instruments and data collection}

The companies surveyed are coded as Company A and Company B. Company A, a company providing ground and passenger handling services in various airports around the world with the headquarters in Vilnius airport and Company B, the company providing technical maintenance services with its aircraft maintenance hangars across various countries and the headquarters in Vilnius airport. In the surveyed companies the researchers conducted deep, semistructured detailed interviews with two head managers of the Human Resource Departments (one in each company) and 8 hangar/ramp employees (4 in each company; this sample was chosen once the answers to the questions in the questionnaire yielded no significant new findings).

The interviews started with the more general questions about non-formal and informal learning conditions provided to employees according to the opinion of

Table 2: Highlights of the research instrument

\begin{tabular}{|c|c|c|}
\hline \multicolumn{2}{|c|}{$\begin{array}{l}\text { Non-formal and informal } \\
\text { learning conditions }\end{array}$} & \multirow{2}{*}{$\begin{array}{l}\text { Interview question areas } \\
\text { Exposure to changes. } \\
\text { Trainings and courses provided on change management, } \\
\text { how to deal with non-standard, non-typical situations. } \\
\text { Other learning possibilities available to deal with changes } \\
\text { and non-standard situations. }\end{array}$} \\
\hline I & $\begin{array}{l}\text { A high degree of exposure to } \\
\text { changes }\end{array}$ & \\
\hline II & $\begin{array}{l}\text { A high degree of exposure to } \\
\text { demands }\end{array}$ & $\begin{array}{l}\text { The level and amount of requirements for employees. } \\
\text { The pressure to renew and improve skills. } \\
\text { Accountability for the new team members. } \\
\text { Expectation to learn from more experienced colleagues. }\end{array}$ \\
\hline III & Managerial responsibilities & Requirement to take managerial responsibilities \\
\hline IV & $\begin{array}{l}\text { Extensive professional } \\
\text { contacts }\end{array}$ & $\begin{array}{l}\text { Ways to develop and maintain professional relations inside } \\
\text { and outside of the company. } \\
\text { The usefulness of professional relations. } \\
\text { The encouragement of the company to expand professional } \\
\text { relations. }\end{array}$ \\
\hline $\mathrm{V}$ & Superior feedback & $\begin{array}{l}\text { Feedback provided by supervisors, both positive and } \\
\text { negative. } \\
\text { Opportunities to improve after negative feedback. }\end{array}$ \\
\hline VI & $\begin{array}{l}\text { Management support for } \\
\text { learning }\end{array}$ & $\begin{array}{l}\text { The ways company encourages training and learning. } \\
\text { The sufficiency of technical and other trainings. } \\
\text { The quality of trainings provided. }\end{array}$ \\
\hline VII & Rewarding proficiency & $\begin{array}{l}\text { Incentives for good performance (monetary and non- } \\
\text { monetary). } \\
\text { Trainings as an incentive. }\end{array}$ \\
\hline
\end{tabular}

Source: based on Skule (2004) 
HR managers and employees themselves. The more specific questions used in this investigation were formed according to the model developed based on the Skule's (2004) quantitative survey on the conditions for non-formal and informal learning in the workplace (See Table 2). The questions used served as guidance whilst the more interesting and unique answers led to more probing in the particular area identified.

The questionnaires for HR professionals and hangar/ramp employees were different, although they addressed the same conditions to enable the identification of any gaps in particular areas of investigation. The questionnaires administered to HR managers contained a more professional language since the respondents were highly familiar with the terminology due to their officially held positions. The questionnaire for hangar/ramp employees was constructed based on the information gathered during the interviews with HR managers. It contained less terminology.

\section{FINDINGS}

First, a general view of the non-formal and informal learning conditions was investigated. Interestingly, both HR managers focused on describing learning/training opportunities for new employees rather than talking about the overall learning conditions within the companies. Naturally, in the segment of ground handling services, the period of time needed for an employee to become a full-fledged team member (around a month, Company A) was significantly shorter than in the aircraft technical maintenance segment (around 5 years, Company B). This comes to show that Company B may rely on in-house training more than Company A. Employees of both companies reflected rather positively on the training opportunities provided in the company ('everything that you need for your job', '100\%').
Also HR managers pointed towards a certain natural transition from non-formal to informal leaning (first, non-formal courses such as safety, fire prevention etc., then informal, as in learning with the help of a superior/mentor/colleague). According to the HR manager of Company A, production meetings are the main arenas for informal learning in the company ('the staff discussing the events that have gone wrong and how it should be done'). The HR manager of Company B mentioned the following ways of informal learning: employees mostly learn independently, by reading the material and learning from working with the assigned senior staff member. Employees of both companies agree that they do intensely learn in an informal manner on a daily basis: 'on the spot', 'from lips to lips' [meaning 'word of mouth'], 'you can learn something new every day'.

The HR manager and employees in Company A do not agree whether nonformal or informal learning is more effective. According to the HR manager of Company $\mathrm{A}$, the ramp employees in the company learn more during the provided courses $(70 \%)$. The ramp employees, on the contrary, stated that they learn more in the workplace (ranging from $50 \%$ to $75 \%$ ) and workplace learning is more successful. It is noteworthy that the employees emphasized the need for the synergy between theoretical and practical training ('You can learn a lot from pictures, but in real view it is not always the same', 'there are as many things that you cannot do without practice as you cannot do without theory') whereas the manager expressed herself strongly about the superiority of learning during courses ('Once you learn, there can be no deviations').

The perceptions of the HR manager were much more consistent with the experiences of hangar employees in the case of Company 
B. The manager was firm about his opinion that the employees learned more every day, in the workplace. The hangar employees assigned as much as $90 \%$ ( $80 \%$ on average) of all knowledge gained as a product of every day, i.e. informal, learning. The reasons for that, again, revolved largely around the need to 'touch, feel and get to the aircraft'.

\section{High degree of exposure to changes}

When asked whether ramp employees were frequently faced with changes, at first the HR manager of Company A stated that everything in the ramp was based on standards and procedures, suggesting a minimal exposure to changes. However, later she rather corrected herself by saying that there are certain external changes or extra situations ('it does not happen often, but if some rules change, airlines or extra situations, when there is a need to put down fires...'), but still maintaining that there is a limited number of changes faced by the ramp employees in the company.

The HR manager of Company B was a lot firmer by stating that 'There is no space for variations' and stressed the need of sticking strictly to instructions, even when placing a simple screw.

However, the perceptions of ramp and hangar employees significantly differed from the opinions of the HR managers. The phrases used by the Company A ramp employees included 'definitely yes' and 'all the time'. Company $\mathrm{B}$ hangar employees were even more open. They provided some very concrete examples. These were largely related to the need of improvising with regard to the lack of a particular tool or equipment.

Surprisingly, despite the stated presence of changes and non-standard situations in their everyday work, the employees of both companies did not see much need for spe- cial courses aimed at facilitating the management of changes and non-standard situations. However, some employees tended to stress that they themselves would not need to undergo such changes, but shared several examples of their colleagues losing the nerve during stressful situations ("For example, they make some sort of mistake, some defect. There is a person, to look at it instantly, I have seen a person go white [meaning pale, int.] and that's it - he cannot work and sits there all being white, trembles, because he is afraid of that... that responsibility that can be assigned to him, but he has made that mistake incidentally,' said one of the Company B employees). This may be partially attributed to the fact that in the entirely male team, the respondents were unwilling to recognize that they themselves might be in need of such training which could suggest their notion of inability to deal with stressful situations as rather non-masculine.

\section{High degree of exposure to demands}

The Company A HR manager similarly to the employees of both companies stated that the demands towards the technical employees were definitely high and also higher than the ones of the perceived competitors. The main reason why the demands were higher was related to poorer infrastructure or resources ("we try, probably, to do as our management says, cheaper, whilst having to do it faster and of higher quality', 'it is just that at ours everything happens at extra speed.'). Only the HR manager of Company B did not think that the demands were somewhat higher than in other companies and referred to the high role of regulations.

According to the HR managers of both companies, the pressure to continuously renew and improve the skills of hangar employees stemmed from the regulatory requirements to do so. In the meantime, although the ramp employees in Company 
A tended to also refer to the regulatory requirements, they emphasized the personal initiative ('if you are interested, of course'). The answers provided by the Company B hangar employees were a bit different. They could not agree whether the company would want employees to improve their skills from their own pocket or not.

There was bigger disagreement on the responsibility for the work of less experienced colleagues in Company B. The HR manager did not think that the more experienced employees felt responsible for the work of less experienced colleagues. The majority of hangar employees, on the other hand, tended to feel such responsibility (,If they are working with me, then it is me who is responsible... ').

\section{Managerial responsibilities}

The next group of questions was aimed at establishing the presence of managerial responsibilities involved in daily activities. The HR managers were asked whether they thought that the companies' ramp or hangar employees had to make many decisions requiring responsibility. The HR managers of both companies had no hesitation over the fact that the number of such decisions was rather high. When asked about the ways that these decisions were made, the HR manager A, though, stated that they were made more individually, while the HR manager B was certain that the process involved team effort ('on the principle of minimum four eyes').

The Company A ramp employees tended to agree with their HR manager, stating that in aviation, the responsibility was always high. However, the cases where the decisions were made individually happened more frequently: ' $80 \%$ individually and $20 \%$ by discussing'. The Company B hangar employees also agreed with the HR manager in stating that they had to make many decisions implying responsibility.

\section{Extensive professional contacts}

The following group of questions was aimed at establishing the presence of a culture aimed at promoting the development of professional contacts in the companies. The HR manager of Company A was positive that the ramp employees in the company did, in fact, maintain professional relations via a specially dedicated Facebook group where the current and previous employees could stay in touch, some team building activities, trips to a bowling alley and the positive atmosphere itself. The HR manager of Company $\mathrm{B}$ was of the opinion that professional relations are indeed built during training courses and work practice, but this is not encouraged by the company.

The majority of Company A ramp employees named the basketball team, Facebook group and general every day communication as the means for developing and expanding professional relations. Many of them mentioned the so called 'pre-signings', referring to parties organized when welcoming a new employee to the team. Similar findings were revealed by Company B employees. As concerns the company's role, some employees went as far as to say that it was not useful for the company to encourage the expansion of professional contacts outside of the company itself because in this way they risk losing the employees they have invested in.

\section{Superior feedback}

According to the HR manager of Company A, the dominant forms of feedback were either promoting employees to a higher position or undertaking disciplinary actions upon the unfavorable behavior or poor performance. There was no mention of such 
appraisal forms as annual conversations or special meetings. On the other hand, the HR manager of Company B considered regular evaluations necessary in the workplace and explained that the performance of the hangar employees was evaluated on regular basis.

The majority of ramp employees at Company A considered that their work results were evaluated solely when they did something wrong ('How to say, eh, nobody tells you about how well you have done that flight or something', 'Well, at ours the feedback comes only when you mess something up'). The hangar employees of Company B, on the other hand, distinguished between two forms of evaluation - verbal feedback that they would receive from their direct superior ('For example, well done, well, today - you have done everything well... ) and the annual evaluation. Same as in the case of Company A, Company B possesses an underlying culture of 'no feedback means good feedback'.

The internal culture of both the ramp and the hangar created a rather positive feedback giving culture amongst colleagues and direct superiors in the immediate teams. However, the formal evaluation system emphasized negative results more.

\section{Management support for learning}

HR manager of Company A responded that training is encouraged by the shift leaders and more experienced employees, whilst the HR manager of Company B said the company's pay system encourages employees to learn more ('it is formed in the way that we could orientate employees towards a certain direction, in his behavior, his wish to show interest in certain novelties, step a bit outside of his responsibility borders...'). Employees of both companies agreed that the amount of technical training provided by their company was sufficient.
Both HR managers, however, stressed that they would wish to have the ability to provide more training on the so called soft skills, yet could not do so at that moment due to the lack of resources. The Company A ramp personnel, however, expressed little interest in receiving such ('everything that we need for doing the job, we know everything ${ }^{6}$ ). The opinions among the Company B employees differed. Whilst some of the employees stated that they would like to receive such training (e.g. English language and team work), whilst others did not consider such training necessary.

\section{Rewarding proficiency}

The last block of questions was designed to establish the condition of the rewarding of proficiency as a facilitating factor for encouraging non-formal and informal learning. The HR manager of Company A said that the most common incentive is the expression of gratitude through issuing a special notice in the company's newsletter upon receiving a thank you letter from certain airlines and organizing the awards of the best employees per department. The HR manager of Company B stated that the system of remuneration was designed specifically to incentivize employees for demonstrating great work results in the company ('Work pay system, which depends on two things your official experience [...] and the other [...] evaluated according to certain criteria that is team work, the aforementioned ability to demonstrate interest outside of one's own area, initiative, discipline and responsibility").

When asked the same question, the Company A ramp employees mentioned monetary bonuses and some ways of recognition. The bonuses were taken away for undesirable behavior as opposed to being given as an incentive for good working results, which may be the reason for most employees to not consider bonuses as an 
incentive at all. In the meantime, Company $\mathrm{B}$ hangar employees would mention bonuses and the awards issued to hangar employees during the annual company party. They tended to mention verbal gratitude from the direct superiors rather than from the company management. Despite stating the importance of monetary incentives, the HR managers and employees of both companies also said that they valued non-monetary form of incentives as well.

The HR manager and employees of Company B were more convinced than the HR manager and employees of Company A that an opportunity to participate in some sort of training can be treated as an evaluation for great working results. Several Company B employees stated that they might choose technical training as opposed to a monetary reward, given the choice.

\section{DISCUSSION}

The analysis of the obtained data was performed in accordance with the learning conditions identified by Skule (2004) and it resulted in two tables for each of the researched companies. Table 3 represents the findings in the Company A. From all of the conditions, based on the experiences of ramp employees, the unfavorable ones included the presence of extensive professional contacts, superior feedback and rewarding of proficiency. It complements the findings of Kyndt et al. (2009) and Schurmann and Beausaert (2016) who demonstrated the significance of supervisor feedback.

The gap between the HR manager's perception and the company ramp employees' experience was rather large as concerns the conditions of managerial

Table 3: The condensed findings in Company A

\begin{tabular}{|l|l|l|l|l|}
\hline \multicolumn{1}{|c|}{ Condition } & $\begin{array}{c}\text { Company } \\
\text { A HR } \\
\text { manager }\end{array}$ & $\begin{array}{c}\text { Company } \\
\text { A ramp } \\
\text { employees }\end{array}$ & $\begin{array}{c}\text { A gap between } \\
\text { HR and } \\
\text { employees' } \\
\text { answers }\end{array}$ & \multicolumn{1}{|c|}{ Favorable condition? } \\
\hline $\begin{array}{l}\text { A high degree of } \\
\text { exposure to changes }\end{array}$ & $\begin{array}{l}\text { Low/non } \\
\text { existent }\end{array}$ & $\begin{array}{l}\text { High/very } \\
\text { high }\end{array}$ & Big gap & $\begin{array}{l}\text { Favorable, yet } \\
\text { unrecognized by the HR } \\
\text { manager }\end{array}$ \\
\hline $\begin{array}{l}\text { A high degree of } \\
\text { exposure to demands }\end{array}$ & $\begin{array}{l}\text { High/ very } \\
\text { high }\end{array}$ & $\begin{array}{l}\text { High/ very } \\
\text { high }\end{array}$ & No gap & $\begin{array}{l}\text { Favorable, recognized by } \\
\text { the HR manager }\end{array}$ \\
\hline $\begin{array}{l}\text { Managerial } \\
\text { responsibilities }\end{array}$ & Low & $\begin{array}{l}\text { High/ very } \\
\text { high }\end{array}$ & Big gap & $\begin{array}{l}\text { Favorable, yet } \\
\text { unrecognized by the HR } \\
\text { manager }\end{array}$ \\
\hline $\begin{array}{l}\text { Extensive professional } \\
\text { contacts }\end{array}$ & $\begin{array}{l}\text { Low/ rather } \\
\text { low }\end{array}$ & $\begin{array}{l}\text { Low/ rather } \\
\text { low }\end{array}$ & No gap & $\begin{array}{l}\text { Unfavorable, not perceived } \\
\text { as important by the HR } \\
\text { manager }\end{array}$ \\
\hline Superior feedback & $\begin{array}{l}\text { High/ rather } \\
\text { high }\end{array}$ & $\begin{array}{l}\text { Medium } \\
\text { high }\end{array}$ & Small gap & $\begin{array}{l}\text { Slightly unfavorable, needs } \\
\text { improvement }\end{array}$ \\
\hline $\begin{array}{l}\text { Management support } \\
\text { for learning }\end{array}$ & $\begin{array}{l}\text { High/ rather } \\
\text { high }\end{array}$ & No gap & $\begin{array}{l}\text { Highly favorable, perceived } \\
\text { as important by the HR } \\
\text { manager }\end{array}$ \\
\hline Rewardingproficiency & Medium & $\begin{array}{l}\text { Medium/ } \\
\text { low }\end{array}$ & Gap & $\begin{array}{l}\text { Rather unfavorable, not } \\
\text { fully perceived by the HR } \\
\text { manager }\end{array}$ \\
\hline
\end{tabular}


responsibilities (the employees tended to think that their job entailed a very large degree of responsibility, whilst the HR manager assigned less responsibility to the place. This was largely to do with the system of bonuses. The fact that employees were 'punished' by the removal of bonuses rather than rewarded with the monetary incentives

Table 4: The condensed findings in Company B

\begin{tabular}{|l|l|l|l|l|}
\hline \multicolumn{1}{|c|}{ Condition } & $\begin{array}{c}\text { Company } \\
\text { B HR } \\
\text { manager }\end{array}$ & $\begin{array}{l}\text { Company } \\
\text { B hangar } \\
\text { employees }\end{array}$ & $\begin{array}{c}\text { A gap between HR } \\
\text { and employess } \\
\text { answers }\end{array}$ & Favorable condition? \\
\hline $\begin{array}{l}\text { A high degree of } \\
\text { exposure to changes }\end{array}$ & $\begin{array}{l}\text { Medium/ } \\
\text { low }\end{array}$ & $\begin{array}{l}\text { High/ very } \\
\text { high }\end{array}$ & Rather big gap & $\begin{array}{l}\text { Favorable, yet partially } \\
\text { unrecognized by the } \\
\text { HR manager }\end{array}$ \\
\hline $\begin{array}{l}\text { A high degree of } \\
\text { exposure to demands }\end{array}$ & $\begin{array}{l}\text { High/ very } \\
\text { high }\end{array}$ & $\begin{array}{l}\text { High/ very } \\
\text { high }\end{array}$ & No gap & $\begin{array}{l}\text { Favorable, recognized } \\
\text { by the HR manager }\end{array}$ \\
\hline $\begin{array}{l}\text { Managerial } \\
\text { responsibilities }\end{array}$ & $\begin{array}{l}\text { High/ very } \\
\text { high }\end{array}$ & $\begin{array}{l}\text { High/ very } \\
\text { high }\end{array}$ & No gap & $\begin{array}{l}\text { Favorable, recognized } \\
\text { by the HR manager }\end{array}$ \\
\hline $\begin{array}{l}\text { Extensive } \\
\text { professional contacts }\end{array}$ & $\begin{array}{l}\text { Medium/ } \\
\text { low }\end{array}$ & $\begin{array}{l}\text { Medium/ } \\
\text { rather low }\end{array}$ & No gap & $\begin{array}{l}\text { Unfavorable, partially } \\
\text { recognized by the HR } \\
\text { manager }\end{array}$ \\
\hline Superior feedback & $\begin{array}{l}\text { High/ } \\
\text { rather high }\end{array}$ & Medium & Small gap & $\begin{array}{l}\text { Slightly unfavorable, } \\
\text { needs improvement }\end{array}$ \\
\hline $\begin{array}{l}\text { Management support } \\
\text { for learning }\end{array}$ & $\begin{array}{l}\text { High/ } \\
\text { rather high }\end{array}$ & $\begin{array}{l}\text { High/ rather } \\
\text { high }\end{array}$ & No gap & $\begin{array}{l}\text { Highly favorable, } \\
\text { perceived as important } \\
\text { by the HR manager }\end{array}$ \\
\hline $\begin{array}{l}\text { Rewarding of } \\
\text { proficiency }\end{array}$ & Medium & Medium & Gap in structure & $\begin{array}{l}\text { Rather unfavorable, } \\
\text { need systematic } \\
\text { changes }\end{array}$ \\
\hline
\end{tabular}

decisions made by ramp agents on a daily basis).

The same applies to the condition of exposure to changes. This can be well related to the fact that in the first group of general questions the HR manager thought that the employees working in the ramp learnt more during courses than from performing their daily routines. According to the experiences of ramp employees themselves, they in fact learned much more from daily practice, thus implying that the changes and non-standard, non-typical situations were much more frequent than perceived by the HR manager. Another gap was related to the condition of rewarding the proficiency in the work- largely affected their lack of perception of such bonuses as a form of reward for proficiency. Just like in the research described by Lohman (2000) where the lack of rewards for learning inhibited informal learning.

Rather similar results to those in Company A were found in the case of Company B (Table 4). Out of all the conditions only three were found to be to a varying degree unfavorable for facilitating non-formal and informal learning in the workplace for Company $\mathrm{B}$ hangar employees. These included extensive professional contacts, superior feedback and rewarding of proficiency. Although the areas calling for attention were the same as in the Company A's case, the 
reasons were rather different. Firstly, the company did not encourage the development of extensive professional contacts in the company and outside of its borders thus depriving the company's hangar employees from the opportunity of exchanging knowledge about the best practices of the industry. This can be also largely related to the gap between the HR manager's perceptions and the experiences of the hangar employees as concerns the amount of non-standard situations encountered in the working environment. The condition of subjecting hangar employees to superior feedback was a bit unfavorable due to the company's failure to set out clear criteria when evaluating their employees as well as the tendency to 'punish' hangar employees for mistakes rather than acknowledge their good performance.

On the whole, the interviews with the HR managers (especially the manager of Company B) have revealed the problem of defining the non-formal and informal learning, as identified in the literature review. It must be stated, though, that the problem even more emphasized due to the issues of translating the terms into Lithuanian. This can be seen from the answers provided in the group of general questions. Despite the initial definitions provided in the introduction to the questionnaire, the managers tend to refer to non-formal learning as informal learning activities and emphasize the formal aspects of non-formal training provided to the employees in the company. The misperception of the terms was also reported by Eraut (2011) in the previous research.

Also, same as in the research conducted by Bondarouk, Looise and Lempsink (2009), in both companies the HR functions were not as clearly defined, so a lot of responsibility for the training of both the ramp and the hangar employees was partially coordinated by the line managers and the HR department.
Moreover, the HR managers' awareness, especially in the case of non-formal training in Company B and informal training in Company $\mathrm{A}$, was rather vague, based on personal opinions rather than clear knowledge based on particular facts (similar to Chivers, 2011). This was also in line with the large proximity (not in a geographical sense) of the HR department and the hangar working environment as a concern expressed by hangar employees during the interviews.

The results of the empirical research have also revealed that in both companies the amount of learning through on-the-job experience was around $70 \%$, which is the same as identified in the research of Michaels et al. (1997) and the research of other scholars presented in the literature review section. Moreover, both HR managers have underestimated this amount of on-the-job experience and thus it may suggest an insufficient focus on improving the learning conditions to facilitate the development of appropriate skills.

Due to larger availability of non-formal training opportunities (training courses), as discussed in the section on learning in the aviation sector, both HR managers and the majority of hangar and ramp employees of both companies tended to discuss specialized training courses more extensively, yet the technical personnel of the companies used more real-life examples related to informal learning. This confirms the notion that informal learning is not necessarily consciously perceived as learning per se. For instance, although declaring a large amount of learning in a workplace as opposed to learning in courses, many respondents struggled to recall the last time they have learned something important in the workplace.

Learning conditions in the aviation sector are similar to the ones described in the literature analysis. However, the practical 
improvements are possible. Whilst complaining about the lack of funding provided by the companies for organizing additional, not just technical training, the HR managers failed to address certain areas that could be improved without the need for significant investment. For instance, only one Company $\mathrm{B}$ hangar employee mentioned a specifically dedicated group on one of the social networks where the representatives of their profession shared their experiences with regard to best practices. The HR management of both companies should encourage such exchange of information through creating virtual communities of practice and organizing specific events designed to facilitate the spread of good practice.

The existing gaps between the perceptions of HR managers and the experiences of technical staff have also revealed the need to bring the HR departments closer to the technical facilities. Moreover, by providing technical staff with more information about the evaluation of their work results accompanied with the improved culture of providing positive feedback in the companies could largely improve employee motivation and the sense of belonging. This is especially important in the aviation industry which is known for its harsh global competition as concerns the limited availability of talented workforce. In the words of one Company B hangar employee, with the open border and highly uncompetitive salaries as compared to foreign employers, Company B should seek ways to incentivize their employees and show extra appreciation.

The potential limitations of this study lie within the fact that the research was conducted in Lithuanian which lacks adequate terminology in the area of human resource management and learning related issues. That is why it was difficult to formulate questions which are easy to understand and represent the theoretical concepts. Moreover, the airport zone is a very strictly regulated area and the scope of the research was largely limited to the timeframe provided for gathering information. Moreover, in the case of Company B, many hangar employees are native Russian speakers and this posed a difficulty in analyzing their responses provided in Lithuanian. However, in certain cases the interviewer urged the respondents to specify the meanings of some phrases used and asked to illustrate the answers with relevant examples. Overall, the researchers had no doubts about the credibility of the results as almost all respondents were relaxed during the interviews and did not avoid revealing unfavorable information about the company or its practices.

As concerns the transferability of results, the fact that the same areas requiring additional attention were established in both companies (suggesting replicability) and much of the results corresponded to the findings of other researchers in the field, the results of the study are likely to be highly transferable to other highly learning-intensive technical fields. However, the study would largely benefit from repeat interviews after a certain period of time or could be expanded to include more technical departments within the companies.

\section{CONCLUSIONS}

The study has revealed that aviation technical personnel worked in highly learning intensive environments with several areas for improvement, such as the need for superior feedback, the development of professional contacts and the rewarding of proficiency. Moreover, it has provided an insight into the existing gaps between the perceptions of HR managers and the experiences of technical staff as concerns the learning conditions in 
the airport hangar and ramp environments. This comes to suggest that the managers should familiarize themselves better with the learning conditions in the technical departments and reduce the existing gap by minimizing the symbolic proximity between the ramp and hangar employees. This can be done by a more active provision of information, establishment of communities of practice and adjusting the system of superior feedback giving as well as fostering the appropriate rewarding of proficiency.

The areas discussed should also raise the concern of other managers working in

\section{References}

1. Air Transport Action Group (ATAG). Retrieved from http://www.atag.org/ facts-and-figures.html. Viewed on August 17, 2017.

2. Alonderienè, R. (2010). Enhancing informal learning to improve job satisfaction: Perspective of SMEs managers in Lithuania. Baltic journal of management, 5(2), 257-287.

3. Baert, H. and Govaerts, N. (2012). Learning patterns of teams at the workplace. Journal of Workplace Learning, 24 (7/8), 538 - 550.

4. Bauer,J. and Mulder, R.H. (2006). Upward feedback and its contribution to employees' feeling of self-determination. Journal of Workplace Learning, 18(7/8), 508 - 521.

5. Becker, K., \& Bish, A. (2017). Management development experiences and expectations: informal versus formal learning. Education+ Training, 59(6), 565-578

6. Bjørk, I.T., Tøien, M. and Sørensen, A.L. (2013). Exploring informal learning among hospital nurses. Journal of Workplace Learning, 25(7), 426 - 440. highly learning-intense 'high reliability' environments, especially in large companies where the HR function is less clearly defined and there is an insufficient culture of both upward and downward feedback giving.

Finally, the study has revealed many areas that require further investigation, primarily as concerns a number of unfavorable areas and the communication between HR professionals and technical departments. The findings call for immediate attention not only companies'- but also industry-wide.

7. Bondarouk, T., Looise, J.K. and Lempsink, B. (2009). Framing the implementation of HRM innovation: HR professionals vs line managers in a construction company. Personnel Review, 38(5), 472 - 491

8. Børgesen, K., Børgesen, K., Nielsen, R. K., Nielsen, R. K., Henriksen, T. D., \& Henriksen, T. D. (2016). Exploiting formal, non-formal and informal learning when using business games in leadership education. Development and Learning in Organizations: An International Journal, 30(6), 16-19.

9. Brett, J.F. and Atwater, L.E. (2001). 360-degree feedback: accuracy, reactions, and perceptions of usefulness, Journal of Applied Psychology, 86(5), 930-42.

10. Cheetham, G., \& Chivers, G. (2001). How professionals learn in practice: an investigation of informal learning amongst people working in professions. Journal of European industrial training, 25(5), 247-292.

11. Chivers, G. (2011). Supporting informal learning by traders in investment banks. Journal of European Industrial Training, 35(2), 154-175. 
12. Clarke, N. (2005). Workplace learning environment and its relationship with learning outcomes in healthcare organizations. Human Resource Development International, 8:2, 185-205.

13. Ellström, P.E. (2010). Practice-based innovation: a learning perspective. Journal of Workplace Learning, 22(1/2), 27 $-40$.

14. Eraut, M. (2011). Informal learning in the workplace: evidence on the real value of work-based learning (WBL). Development and Learning in Organizations: An International Journal, 25(5), 8-12.

15. Eurostat, A Memorandum on Life-long Learning (2000). Retrieved from http:// www.bologna-berlin2003.de/pdf/MemorandumEng.pdf

16. Eurostat, Classification of learning activities -Manual (2006). Retrieved from http://www.uis.unesco. org/StatisticalCapacityBuilding/ Works hop \% $20 \mathrm{Document} /$ Education $\% 20$ works hop $\% 20$ dox/2010\%20ISCED\%20TAP\%20 IV\%20Montreal/NFE CLA Eurostat EN.pdf

17. Fedor, D.B., Eder, R.W. and Buckley, M.R. (1989). The contributory effects of supervisor intentions on subordinate feedback responses. Organizational Behavior and Human Decision Processes, 44, 396-414.

18. Flin, R., O'Connor, P. and Mearns, K. (2002). Crew resource management: improving team work in high reliability industries. Team Performance Management, 8(3/4), 68 - 78 .

19. Garnett, J., \& Cavaye, A. (2015). Recognition of prior learning: opportunities and challenges for higher education. Journal of Work-Applied Management, 7(1), 28-37.
20. Gijbels, D., Raemdonck, I., Vervecken, D. and Herck, V.J. (2012). Understanding work-related learning: the case of ICT workers. Journal of Workplace Learning, 24(6), pp. 416 - 429.

21. Grant Wofford, M., Ellinger, A. D., \& Watkins, K. E. (2013). Learning on the fly: exploring the informal learning process of aviation instructors. Journal of Workplace Learning, 25(2), 79-97.

22. Ha, T. S. (2008). How IT workers learn in the workplace. Studies in Continuing Education, 30(2), 129-143.

23. Hagemann, V., Kluge, A. and Ritzmann, S. (2012). Flexibility under complexity: Work contexts, task profiles and team processes of high responsibility teams. Employee Relations, 34(3), 322 - 338.

24. Henriksen, T. D., \& Børgesen, K. (2016). Can good leadership be learned through business games?. Human Resource Development International, 19(5), 388-405.

25. Hunter, J., \& Cox, A. (2014). Learning over tea! Studying in informal learning spaces. New Library World, 115(1/2), 34-50.

26. Kazlauskaitè, R.' and Bučiūnienè, I. (2010). HR function developments in Lithuania. Baltic Journal of Management, 5(2), 218-241.

27. Kim, Y., \& Park, H. (2014). An investigation of the competencies required of airline cabin crew members: The case of a Korean airline. Journal of Human Resources in Hospitality \& Tourism, 13(1), 34-62.

28. Kyndt, E., Dochy, F. and Nijs, H. (2009). Learning conditions for nonformal and informal workplace learning. Journal of Workplace Learning, 21(5), 369-383.

29. Kyndt, E., Govaerts, N., Keunen, L., \& Dochy, F. (2013). Examining the learn- 
ing intentions of low-qualified employees: A mixed method study. Journal of workplace learning, 25(3), 178-197.

30. Kyndt, E., Kyndt, E., Vermeire, E., Vermeire, E., Cabus, S., \& Cabus, S. (2016). Informal workplace learning among nurses: Organisational learning conditions and personal characteristics that predict learning outcomes. Journal of Workplace Learning, 28(7), 435-450.

31. Lohman, M. C. (2000). Environmental inhibitors to informal learning in the workplace: A case study of public school teachers. Adult Education Quarterly, 50(2), 83-101.

32. Lohman, M. C. (2006). Factors influencing teachers' engagement in informal learning activities. Journal of workplace learning, 18(3), 141-156.

33. Madzar, S. (1997). Hungry for feedback? Management Development Review, 10(7), 246 - 248.

34. Malcolm, J., Hodkinson, P. and Colley, H. (2003). The interrelationships between informal and formal learning. Journal of Workplace Learning, 15(7/8), 313-318.

35. Mavin, T. J., \& Roth, W. M. (2015). Optimizing a workplace learning pattern: a case study from aviation. Journal of Workplace Learning, 27(2), 112-127.

36. Meyer, H.H. and Walker, W.B. (1961). A study of the factors relating to the effectiveness of a performance appraisal program. Personnel Psychology, 14, 291-8.

37. Michaels, E., Handfield, H. and Axelrod, B. (1997). The war for talent. Boston, MA: Harvard Business School.

38. Mok, O. N. A. (2011). Non-formal learning: Clarification of the concept and its application in music learning. Australian Journal of Music Education, (1), 11-15.
39. Mulder R.H., Ellinger, A.D. (2013). Perceptions of quality of feedback in organizations: Characteristics, determinants, outcomes of feedback, and possibilities for improvement: introduction to a special issue. European Journal of Training and Development, 37(1), 4 23

40. Schürmann, E., \& Beausaert, S. (2016). What are drivers for informal learning? European Journal of Training and Development, 40(3), 130-154.

41. Skule, S. (2004). Learning conditions at work: a framework to understand and assess informal learning in the workplace. International Journal of Training and Development 8(1), 8-20.

42. Vaiginienė,E.,Alonderienè, R.,,Pilkienè, M., Ramonienè, L., Savanevičienė, A. ir Stankevičiūtè, Ž. (2018). Management and leadership Development Needs - the case of Lithuania. Management and leadership Development Needs in Dynamically Changing Societies. Ed. Purg, D., Braček Lalić, A. and Pope, $J$. Springer International Publishing (in press)

43. Wofford, M.G., Ellinger, A. D., \& Watkins, K. E. (2013). Learning on the fly: exploring the informal learning process of aviation instructors. Journal of Workplace Learning, 25(2), 79-97.

44. Zhang, P. and Ng, F.F. (2012). Attitude toward knowledge sharing in construction teams. Industrial Management \& Data Systems, 112(9), $1326-1347$.

45. Zuzeviciute, V. and Tereseviciene, M. (2010). The role of a human resource manager as a facilitator of learning. Some evidence from Lithuania. Baltic Journal of Management, 5(1), 68-81. 


\section{UVJETI NEFORMALNOG I INFORMALNOG UČENJA PREMA PERCEPCIJI TEHNIČKOG OSOBLJA I PROFESIONALACA LJUDSKIH POTENCIJALA}

\section{Sažetak}

Tema ovog rada je istraživanje uvjeta neformalnog $i$ informalnog učenja, kako ih doživljava, u tekućem poslovanju, tehničko osoblje, ali i kako ih percipiraju menadžeri ljudskih potencijala u zrakoplovnoj industriji u Litvi. Rad se temelji na kvalitativnoj istraživačkoj metodologiji, zasnovanoj na dubinskim, polu-strukturiranim intervjuima s dvama menadžerima ljudskih potencijala $i$ osmero tehničkih zaposlenika u dvama najvećim litavskim avio kompanijama. Rezultati istraživanja ukazuju da, iako su uvjeti za učenje u analiziranim poduzećima bili relativno povoljni, $i$ dalje postoji određeni raskorak između percepcije menadžera ljudskih potencijala $i$ doživljaja operativnih zaposlenika, a što se posebno odnosi na područja, u kojima postoji veća izloženost promjenama $i$ veća menadžerska odgovornost.

Ključne riječi: neformalno $i$ informalno učenje, zrakoplovna industrija, menadžeri ljudskih potencijala, tehničko osoblje, Litva 
